\title{
THE MANAGEMENT OF MULTICULTURAL RESOLUTION ON POST-TRANSNATIONALISM OF INDONESIAN ISLAMIC EDUCATION: CHALLENGES FOR THE FUTURE
}

\author{
Muhammad Thoyib \\ State Institute of Islamic Studies (IAIN) Ponorogo \\ Email: thoyib@iainponorogo.ac.id
}

\begin{abstract}
This article discusses the urgency of the post-transnationalism paradigm of Indonesian Islamic education in the multicultural resolution management perspective that its substance discusses at least three main streams of discourse, namely: first, the substance of the post-transnationalism paradigm of Indonesian Islamic education that can be interpreted as an ideology of Islamic education that promotes the importance of moderation values that live within the multiculturalism of this nation, both on madrasas, pesantren and Islamic Higher Education. Secondly, the challenge of multiculturalism in Indonesian Islamic education is this archipelago's problem with the dimensions of social conflict, radicalism, and extreme fundamentalism, which negates the importance of respect for diversity. Third, the multicultural resolution management design of Indonesian Islamic education for world peace must at least carry three main agendas that are very important in realizing the post-transnationalism paradigm in the future, which includes: development of a hu manistic curriculum, strengthening moderation of institutional management, and strengthening institutional scientific partnering networks.
\end{abstract}

Abstrak: Artikel ini mengkaji urgensivitas paradigma post-transnasionalisme pendidikan Islam Indonesia dalam perspektif manajemen resolusi multikulturalisme dengan nilainilai harmoni sosial, toleransi, kemajemukan, kerukunan, sekaligus saling menghargai sebagai kontribusi modal sosial bagi terbangunnya perdamaian dunia. Subtansi artikel ini setidaknya membincang tiga arus utama diskursus yaitu: pertama, subtansi paradigma post-transnasionali s me pendidikan Islam Indonesia yang dapat dimaknai secara interpretatif sebagai ideologi pendidikan Islam yang mempromosikan pentingnya nilainilai moderasi yang hidup dalam aras multikulturasme kebangsaan, baik pada etalase pendidikan madrasah, pesantren maupun perguruan tinggi Islam keagamaannya. Kedua, tantangan mu 1 tikulturalisme pendidikan Islam Indonesia merupakan problematika nusantara yang bersifat akumulatif historis yang berdimensi konflik sosial, radikalisme, dan fundamentalisme ekstrim yang menafikan pentingnya penghargaan atas kebhinekaan (diversity). Ketiga, desain manajemen resolusi multikulturalisme 
pendidikan Islam Indonesia untuk perdamaian nusantara dan dunia setidaknya harus mengusung 3 agenda utama yang sangat penting dalam kerangka mewujudkan paradigma post-transnasionalisme pendidikan Islam Indonesia yang ekselen di masa depan, yang mencakup: pengembangan kurikulum pendidikan Islam humanis, penguatan moderasi manajemen kelembagaan pendidikan Islam, serta penguatan jejaring keilmuan yang ditunjang dengan komitmen dan kerjasama keilmuan (knowledge partnering) dalam skala nasional, regional dan internasional.

Keywords: post-transnationalism of Islamic education; challenges; multicultural resolution management

\section{INTRODUCTION}

Islam is the genuine living way that teaches the important values of peace and harmony of human life. The postulation of this view is supported by the historical reality in which the Medina Charter's prestige is clear evidence that Islam carries the mission of preaching and the mission of humanitarian education. In the language of contemporary Muslim scholars, Yusuf al-Qordhawi, in his book, Al-Islam wa Awsatuhu fi al-Tarbawiyyah, Islam is not enough to be seen only as a Shariah religion, but also the religion of civilization which contains the universalism of public educational values. ${ }^{1}$

The universality of Islam as a religion, Rahmatan lil 'Alamin, is manifested in Islam's teachings concerning all aspects of human life, which include creed, shari'ah, and morals. Islam's universality reflects the cosmopolitan values of its adherents, which can be a blessing for nature. ${ }^{2}$ However, most Muslims' comprehensive teachings are not yet fully understood by most Muslims as a whole and proportionally. Various interpretations of differentiation occur, so it is not uncommon for the ambiguity of most Muslims'sthinking to understand the basic substantive principles of Islamic teachings, especially in the dynamics of national multiculturalism.

The outbreak of transnational religious ideologies in a radical homeland lately is one manifestation of the differentiation of religious thought among some Muslims over the substance of Islamic teachings. In contrast, transnational religious patterns are counterproductive to local wisdom and national and world character development. ${ }^{3}$ In this connection, for the context of religious life in

1 Yusuf al-Qordhawi, Al-Islam Wa Awsatuhu Fi al-Tarbawiyah (Lebanon: Dar el-Kalam, 2013).

2 Yasid Ismail, Peace Education and the Challenge of Modernity (New York: David McKay Company, 2006).

3 Tobroni, Relasi Kemanusiaan Dalam Keberagamaan (Mengembangkan Etika Sosial Melalui Pendidikan) (Bandung: Karya Putra Darwa, 2012). 
Indonesia with a pluralistic society, understanding the substance of moderate Islamic teachings has relevance and significance for the peace of world civilization. However, as cited by world Muslim scholars, Naquib al-Attas, Indonesia is 'The axis of world civilization where Indonesian peace means the breath of world peace because Indonesia has potential magnets that bind the existence of world countries. ${ }^{4}$ One of them is the potential of Islamic education with the diversity of localities. Which is so high and valuable (prestigious locality), both in madrassas, pesantren, and Islamic higher education scattered throughout this republic.

Historically, the substance of the Islamic education style in Indonesia cannot be ruled out from the color of archipelago locality, which is so diversified and a very massive global influence. Therefore, that the Islamic civilization which is built in Indonesia does not dissolve in negative and backward local elements and global currents that could invite disasters for Indonesian Islam such as violent behavior in the name of religion ${ }^{5}$, mainstreaming Islamic education in moderate religious values is important actualized in the development of multicultural Islamic educational institutions. Its development can serve to maintain the character of Muslims as Khairu Ummah while bringing world peace in harmony with the vision of Islam as Rahmatan lil 'Alamin.

In this context, it is time for the antithesis of the transnational religious education movement that is endemic and alarming to be further encouraged by its existence as a manifestative effort to world peace civilization. The form of antithesis is none other than 'post-transnationalism of Islamic education in this archipelago' which is expected to accommodate and empower the reality of diversity, both in terms of scientific substance (curriculum) and the institution as the 'main agenda' of Islamic education in Indonesia today. That way, the face of Indonesian multiculturalism in the future will truly be able to make a significant contribution to the birth of peace and harmony of essential social life where the reality of the threat of social conflict, radicalism, extreme fundamentalism, as well as social, economic gaps in society that have been living in the history of this nation and the world, in general, is a more promising 'the illusion of human civilization future.'

\section{POST-TRANSNATIONALISMOFINDONESIANISLAMICEDUCATION: KNOWLEDGE MODERATION WITH MULTICULTURAL FACE}

Post-transnationalism of Islamic education is a term of sociological education interpretation that the author conveys as an autocritical answer to the rise of transnational religious education that is pragmatic, exclusive, intolerant, and

${ }^{4}$ Haqqul Yaqin, Agama \& Kekerasan Dalam Transisi Demokrasi Di Indonesia (elSAQ Press, 2009).

5 Syafi'I Ma'arif, Islam Dan Kedamaian Sosial (Yogyakarta: Bintang Pustaka, 2009). 
tends to deny others' existence groups. Or borrowing the language of Hendrick Bill in Religion and Education in Modern Society as "The only trustest ideology." The only ideology that thinks the most correct, which is counterproductive to peace and social harmony, lives in the human heart's recesses. ${ }^{6}$ Or in terminology, Yasid Ismail called the existence of this transnational education movement 'the killer of human civilization. ${ }^{7}$

The post-transnationalism paradigm, the antithesis of transnationalism, is in harmony with the Indonesian nation and state's identity, historically so famous for the values of tolerance, harmony, pluralism, mutual help, etc. In other words, the post-transnationalism of Indonesian Islamic education is the paradigm of Islamic education that emphasizes the importance of educational values of social harmony, peace, and mutual respect for the motherland's real diversity. It is also in line with madrassas, pesantren, and Islamic higher education in Indonesia, which has been substantially oriented since its inception for the benefit of mankind and the world. And the real evidence that will always be remembered by history is the birth of this nation's independence, which was initiated and driven by madrassas activists, pesantren and universities by embracing all the multicultural potentials of the nation so that the common goals can be accelerated collectively and we can feel and enjoy until now.

In that context, post-t $\mathrm{r}$ ansnationalism of Islamic education can be interpreted as an ideology of Islamic education that carries at the same time promotes the importance of moderation values that live on the multicultural level of nationality. It is also consistent with the educative view of Muhammad Husein Abdurrahman, in $\mathrm{h}$ is monumental book,al-Tarbiyah al-Islamiyah alAsyriyah, who once ever said:

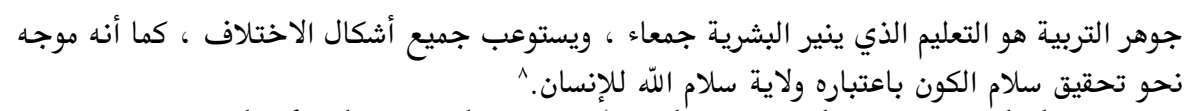

Meaning: Pearl of Islamic education 'is education that gives enlightenment to all mankind, accommodates all forms of difference, while at the same time is oriented to the realization of universal peace as God's peace mandate to humans

This view is also in line with the academic critic from Richard Pratte, who once stressed the transnationalism education ideology's fragility for a nation. He asserted, 'Transnationalism of education is education ideology that is just talking about its self, without seeing other diversities which will bring a nation

${ }^{6}$ Hendrick Bill, Religion and Education in Modern Society (New York: Manhattan Ltd Press, 2014).

7 Ismail, Peace Education and the Challenge of Modernity.

${ }^{8}$ Muhammad Husein Abdurrahman, Al-Tarbîyah al-Islâmîyah al-Asyriyah (Lebanon: Dâr al-Fikr al-'Arabî, 2012). 
into destructive social life. ${ }^{9}$ A scathing critique is relevant to human life's multicultural reality, which is very diverse in culture, language, religion, and ethnicity, especially in Indonesia, where the religious identity is a 'treasure of civilization' that serves as the glue of nationality of its population and becomes the republic's international image in the international world's eyes.

This futuristic orientation is 'agreed' by one of Morocco's contemporary Muslim education experts, Ahmad Syauqi, who emphasized that the main condition for the establishment of peaceful world civilization is the manifestation of moderation values in accommodative Islamic educational institutions, to be able to unravel the tangled thread of radicalism and the future extremism virus that contains at least five main principles of institutional moderation development, namely: (1) developing a comprehensive understanding of Islam, (2) strengthening the balance between the provisions of shari'ah, tarbawiyah, and changing times, (3) increasing support for peace and respect for human values, (4) recognition of religious, cultural, and political plurality, and (5). Recognition of minority rights. ${ }^{10}$

\section{THE CHALLENGE OF INDONESIAN ISLAMIC EDUCATION MULTICULTURALISM: FROM SOCIAL CONFLICTS INTO RADICALISM}

Indonesia is a miniature of a pluralistic world nation. Borrowing the language of Jose A Cardinas, in Multicultural Education: A Generation of Advocacy, as 'nation-state with thousand faces.' ${ }^{11}$ Imagine a country inhabited by about 250 million people has a diversity of religions, ethnicities, languages, and cultures that are so high and massive in the world. ${ }^{12}$ When the national potentials can be managed properly, plurality is a valuable social capital for this nation's civilization and the world. Conversely, suppose it cannot be managed properly. In that case, pluralism can cause conflicts and social friction as 'terrible' as ever happened in Ambon, Maluku, Papua, and Kalimantan a few years ago that claimed more than

\footnotetext{
9 Richard Pratte, Ideology and Education (New York: David McKay Company, 1998).

${ }^{10}$ Ahmad Syauqi, At-Tarbiyah Wa Uslubuha Fi al-Mujtama' al-Asy'ri (Maroko: Dar alKhitab, 2015).

${ }^{11}$ Jose A. Cardinas, Multicultural Education: A Generation of Advocacy (Amerika: Simon and Schuter Custom Publishing, 2014).

12 "The Evidence That Indonesia Is a Pluralistic State Can Be Seen from Indonesia's Diverse Socio-Cultural-Geographical Conditions. Noted, the Number of Islands in Indonesia around 13,000 Islands, Both Large and Small Islands. Its Population Is More than 250 Million People, Consisting of 300 Tribes That Use Nearly 200 Different Languages. In Addition, the Indonesian Population Adheres to Various Religions and Beliefs Such as Islam, Catholicism, Protestant Christianity, Hinduism, Buddhism, Confucianism and Various Religious Traditions. See Also M. Ainul Yaqin, Pendidikan Multikultural: Cross-Cultural Understanding Untuk Demokrasi Dan Keadilan (Yogyakarta: Pilar Media, 2008), p.4.," n.d.
} 
400 people. The historicity of social conflict seems to confirm how the future of peace and harmony in this pluralist republic's social life will continue to face extraordinary challenges due to its 'multicultural' face.

On the other hand, what is just as great is the presence of the wave of storming terrorism and religious radicalism that seem never to stop. Even impressed even more 'epidemic' at such a terrible speed. Look at the history of this republic, especially after the New Order regime's fall, acts of terrorism and radicalism were spread out in the spring. In no more than a decade, terrorism and radicalism alternately shook this pluralist republic. For example, the Bali Bomb I, Bali Bomb II, the Australian Embassy bomb, the JW Marriot I Hotel bomb, the JW Marriot II Hotel bomb, the Ritz Carlton Hotel bomb (range 2001-2011), the "book bomb" aimed at some figures, The "Friday bomb" at the Cirebon Mapolres mosque (range 2012-2013), and the suicide bombing at the Full Gospel Bethel Church (GBIS) Kepunton, Solo (2014), Kuningan Jakarta (2017), radical actions in Yogyakarta (2018), and so on.

The many social conflicts, radicalism, and extreme fundamentalism in Indonesia show that this nation does not fully understand the meaning of diversity and difference. Not a few humans want to eliminate diversity (plurality) and replace it with oneness and uniformity. Ironically, extremists and radicalists claim that all is done because of religious orders (Islam). ${ }^{13}$

This kind of thing certainly cannot be tolerated. Indonesia must improve itself to become a better nation. Among the dimension of life that must be addressed is the world of education. It's recognized or not; education contributes to the formation of an exclusive mindset. In this context, according to the author, Islamic education needs attention. It is because Islamic education has not produced enough tolerant, moderate, and inclusive students. The proof, among others, can be seen from the many perpetrators of terrorism and Islamic radicalism involving youth, both students and Islamic college graduates and pesantren.

The heartbreaking national reality is allegedly a grand design of systematic efforts by certain religious groups to teach hard-line religious doctrine among adolescents, both in schools/madrassas, universities, and even pesantren. It is as confirmed by AzyumardiAzra, Professor of UIN SyarifHidayatullah Jakarta, who said that several studies had proven the existence of systematic recruitment efforts to schools, universities, and pesantren by conducting "brainwashing" of

${ }^{13}$ Ngainun Naim, “'Strategi Penanganan Radikalisme Dan Terorisme Di Indonesia: Perspektif Pendidikan"” (National Simposium about "Memutus Mata Rantai Radikalisme dan Terorisme," Jakarta, July 15, 2011), http://www.lazuardibirru.org/wp-content/uploads/else/ pdf/strategi-penganan-radikaliseme-dan-teroris me.pdf. 
adolescents, which in turn is filled with certain radical ideologies. ${ }^{14}$ Even the results of The Wahid Institute's research in collaboration with the Ministry of Religion Research Institute in 2016 last year confirmed that 10\% of 2,520 highlevel students in 34 provinces in Indonesia were willing to take radical action. ${ }^{15}$ The data collected by The Wahid Institute in 2016 shows clearly that there is an increasing graph of violence in the name of religion, differences in beliefs, and intolerance. Wahid Institute noted that in 2015 there were 63 cases, with an average of 5 cases per month, both individuals or groups. ${ }^{16}$ Even the National Intelligence Agency (BIN) also indicated nationally, in 2017, that Indonesian students who were infected with the radicalism virus had increased by $39 \%{ }^{17}$

These data at least indicate that religion has played its antagonistic function. On the one hand, religion promises happiness, compassion, and peace. On the other hand, it is as if religion has shown its "fierce" face, which has acted as a trigger for conflict, hostility, and violence (radicalization) in the name of religious truth under the pretext of "defending God." Herein lies the problem and challenge of multicultural religious education (Islam) with an insight into the archipelago to prove itself as an advanced, progressive, humanist, positive, open, and humble force.

Islam is the genuine living way that teaches the important values of peace and harmony of human life. The postulation of this view is supported by the historical reality in which the Medina Charter's prestige is clear evidence that Islam carries the mission of preaching and the mission of humanitarian education. In the language of contemporary Muslim scholars, Yusuf al-Qordhawi, in his book, Al-Islam wa Awsatuhu fi al-Tarbawiyyah, Islam is not enough to be seen only as a Shariah religion, but also the religion of civilization which contains the universalism of values public education. ${ }^{18}$ For this reason, the efforts to develop multicultural religious education in Islamic educational institutions today are a necessity as Indonesian post transnationalism. These efforts are building multicultural awareness of the importance of peace and harmony values in social life that is increasingly alarming.

${ }^{14}$ Azyumardi Azra, Pendidikan Islam: Tradisi Dan Modernisasi Menuju Milenium Baru (Logos Wacana Ilmu, 1999).

15 "The Report of Religion Research Institute of Religious Affairs on 2017," accessed April 13, 2019, www/http.balitbang.kemenag.go.id.

16 "The Report of The Wahid Institute on National Seminar about 'Terorisme Dan Radikalisme: Tantangan Kekinian Islam Nusantara”' (UIN Syarif Hidayatullah Jakarta, August 19, 2016).

${ }^{17}$ Republika, April 28, 2018.

${ }^{18}$ Zakiyuddin Baidhawy, Pendidikan Agama Berwawasan Multikultural (Jakarta: Erlangga, 2005). 


\section{MANAGEMENT OF MULTICULTURAL RESOLUTION FOR INDONESIAN ISLAMIC EDUCATION FUTURE AND WORLD PEACE}

The existence of religious ideologies that have been developed by various Islamic educational institutions in Indonesia, ranging from madrassas, pesantren, and Islamic higher education, are substantively varied. On one side, it is a genuine pearl of Indonesian civilization. But on the other hand, its existence can also offer a terrible future if it is not managed properly in accordance with the values of multiculturalism that is inherent in the motherland of this state. So what is the best thing that can be done to design and develop this archipelago's Islamic education with its multicultural face? So that in the future, it is hoped that it will be able to contribute to the building of Indonesian peace and social harmony, but more than that, it will be able to provide a 'rainbow' color for the bright face of world civilization.

In this context, it is time for resolution management to be developed as a soft tool for peace-building tools that can foster tolerance, harmony, and mutual respect in the world of Islamic education in Indonesia, at various levels of education. As confirmed by Hans Luck Pieters in Resolution Management for Multicultural Education, resolution management is not only an effort to re-manage diversity that is torn but more than that as scholarship that can understand the substance of problem from a variety of more comprehensive educational perspectives by looking at various social potentials that 'lives' in society. ${ }^{19}$

In that context too, at least according to the author's perspective, there are three main agendas of resolution management that are very urgent to be realized in the framework of realizing the post-transnationalism paradigm of Indonesian Islamic education in the multicultural state, namely:

\section{Developing Humanistic Islamic Education Curriculum}

Historically, humanistic education is a monumental approach to the work of humanistic psychologists Abraham Maslow and Carl Rogers where humanistic education is interpreted as the center of basic human education which emphasizes that the center of learning success is actually in the sense of empathy, concern for students and dialogic communication in joyful learning construction. ${ }^{20}$ The development of Islamic education curriculum with a humanistic approach is focused on the basics of child psychology, especially the aspects of religious, psychological dimension that starts from a deep sense of empathy, where every

${ }^{19}$ Hans Luck Pieters, Resolution Management for Multicultural Education (New York: Prentice Hall Ltd, 2018).

${ }^{20}$ Clark. F. Power, Moral Education (New York: Greenwood Publishing Group, 1988). 
human being feels what is felt by others, so educators understand the needs of their students and learning has valuable meaning for each student.

The curriculum of humanistic Islamic education makes learning a place for developing the abilities and concerns of educators and students in a more mature synergy cohesion, both on the dimensions of emotionality, intellectuality, and spirituality (common sense of education values). Each activity in learning is a facilitator in understanding individuals. Educators know the basic potential possessed by students so that it is easy to develop their talents. The basic potential of learners can be used as a venue for talent development so that educators act as facilitators and creative and innovative mentors. The existence of mutual concern is the integrated communication that openness and humanistic guided democracy are achieved. In line with Carl Rogers' educative analysis, it also emphasizes "Humanistic education focuses on education as symbolic action, as the foundation of discovery and, thus, as" equipment for living "in improving education in democratic societies." 21

The development of a humanistic Islamic education curriculum is expected to build a good emotional relationship between educators and their students, in the dimensions of objectives, materials, and learning methods that are constructive without losing the eleventy of education values in enjoyable learning. It is in line with Edward McNeil's view in his book, Contemporary Humanistic Curriculum, which emphasizes that the curriculum with a humanistic approach (humanistic curriculum) sees the curriculum as important in helping students to become what they want to be, and emphasizes personal relevance, feelings, and mutual success. ${ }^{22}$

The humanistic Islamic education curriculum is oriented as a guide for implementing in developing teaching materials in accordance with the basic potential of students. Thus, to develop a humanistic Islamic education curriculum that can develop the context in a related manner so that the implementation of learning can later be realized more optimally, educators' humanistic Islamic ethics is needed. In that context, according to the author Michael Grimmit's view, the role of humanist educators is needed to be deeper: (1). Hearing a comprehensive view of learners' reality, (2). Respecting individual students, and (3). Appearing naturally, authentically, and not made up. ${ }^{23}$

${ }^{21}$ Carl Roger, Learning and Teaching Humanist (New York: Commons License: Attribution Non-Commercial, 2015).

${ }^{22}$ Edwind McNeil and John D, Contemporary Humanistic Curriculum (New York: McMahon International Book Ltd., 2013).

${ }^{23}$ Michael Grimmit, Religious Education and Human Development (Great Britarian: McCrimmon, 2012). 
The Islamic education curriculum with a humanistic approach sees Islamic education activities as a benefit for future participants who emphasize the importance of integrity, namely unity of behavior. The Islamic education curriculum is about intellectual, emotional, action, and spiritual humanity, including others. They are (1) integration of all students' affection domains, namely emotions, attitudes, values, and cognition domains; (2) awareness and importance; and (3) response to measure the depth of skill. ${ }^{24}$

The characteristics of a humanistic Islamic education curriculum on this model can be used to provide valuable experience for students and help smooth students' personal development, especially in the aspects of national morality and humanitarian religiosity. A curriculum with such orientation will further foster a high degree of independence, creativity, and innovation for students while providing higher social and morality capability and being precise in 'understanding' and facing life competition more wisely (wise personality) in the public sphere. It is making humans as creatures that can educate and be educated (homo educable) in educative language. ${ }^{25}$

The implication of understanding about the nature and form of humans as homo educable, the Islamic education of this archipelago should take several strategic steps in developing a humanistic Islamic education curriculum, namely: first, the material and methods of Islamic education are more of a giving or providing stimulus so that students automatically respond to them. ${ }^{26}$ Second, educators cannot force them without seeing the basic potential of students. Third, the education process's democratization approach is very relevant for developing basic human potential while instilling confidence and responsibility. Fourth, the process of Islamic education must always refer to the nature of God (theocentric). The substance of Islamic Education is a persuasive and preventive effort in fostering an attitude of respecting every human being's rights, as an alternative being and an exploratory being.

Humans as alternative beings because humans can make choices and live their lives. It is in a position of the blessing of the Divine. Humans as creatures equipped with potential so that with that potential can develop themselves. Thus, humans in Islamic education philosophy are alternative beings but offered the best value choices, namely the divine value. Meanwhile, as explorative creatures, it is because humans have the potential to develop and be developed. Humans are social beings who can develop themselves both physically and psychologically.

\footnotetext{
${ }^{24}$ Ricardo L . Garcia, Teaching in Pluralistic Society (New York: Row Publisher, 2013).

${ }^{25}$ Abdul Mujib Abdul Mujib, Ilmu Pendidikan Islam (Jakarta: Kencana Prenada Media Group, 2007).

${ }^{26}$ Muhammad Thoyib, Model Pengembangan Pendidikan Islam Multikultural Di Indonesia (Ponorogo: STAIN Po-Press, 2016).
} 
In this case, there is a basic potential in humans that can grow and develop normally. This basic potential can develop by requiring guidance from outside himself in accordance with their innate potential (al-fitrah al-tarbawiyyah) so that it can make their innate god identity (ruhiyah-ilahiyah) as a civilization of religious humans.

\section{Strengthening Management Moderation of Islamic Education Institution}

Ex secretary General of Islamic Education Ministry of Religious Affairs, MohIsom as quoted by Republika, once emphasized the need for a moderate national Islamic educational institution's strategic policy and no longer a national education subsystem. He said, "Making Islamic educational institutions as the mainstream of national education is not nonsense. Islamic educational institutions have many advantages that other educational systems do not have. As well as being the forefront of Islamic moderation in Indonesia, Islamic educational institutions are superior in the integration of religion and science needed by this nation's generation." ${ }^{27}$ This orientation is no other because of the futuristic potential of Indonesian Islam as a miniature of world civilization as once echoed by Fazlurrahman, the world's Muslim scholar, in his monumental book, Islam and Modernity. ${ }^{28}$

Institutionally, management moderation of Islamic educational institutions has been an affirmative for the economically vulnerable people, as evidenced by the affordable education cost, while still prioritizing quality. On the other hand, the strength of Islamic educational institutions lies in giving birth to Muslim middle classes who are aware of the existence of this republic's national values as an 'institutional benchmarking' based on the multiculturalism of this archipelago. So far, the main supporters of Islamic educational institutions are Muslim communities in villages that are far to the border area. But in its development, Islamic education institutions can appear as 'first' and 'primary' educational institutions, both in rural and urban areas, both from the lower middle class and upper-middle-class, without distinguishing the "colors of religious and cultural ideology' of people. It is in line with the wise view of RichadGeers, in How To Be a Great Leader, that "Any institution, if you want to achieve success, then manage moderately that allows all potentials of children to enjoy a touch of goodness that will enable for them to become the good people for others." ${ }^{29}$

27 "Republika," March 26, 2017.

${ }^{28}$ Fazlurrahman, Islam and Modernity (New York: Chicago University Press, 1986).

${ }^{29}$ Richard Geers, How to Be a Great Leader: Kiat Sukses Menjadi Pemimpin Besar . Translator. Ariyanto Harahap. (Surabaya: Cahaya Ilmu, 2016). 
The moderation role of Islamic educational institutions that are so important for the future of Indonesian Islam in particular and a world civilization in general, at least in the perspective of the author, it is necessary to strengthen the moderativerole through at least three substantive continuous and simultaneous efforts that are namely: (1). Strengthening the moderation of Islamic education institutional management oriented to developing a comprehensive understanding of Islam; (2). Increasing support for peace and respect for human values; and (3). Recognition of the multicultural religion, culture, and political plurality of Indonesian society.

The opinion is also in line with the recommendations of the Second World Conference on Muslim Education, held on 12-17, February 2013, in Morocco, which reaffirmed the commitment of the worldwide Islamic education conference regarding broad goals, which include educational goals, structure, content, learning and teaching processes, curriculum planning, Islamic educational institutions and so on, which recommends several important things, namely: $:^{30}$ (a) a hierarchy of Islamic education curriculum planning units that is accommodative and responsive should be built to prepare, implement, monitor and evaluate curricula at the ranks of each school, university, national education policy-making rank and coordinating institutions, and international ranking institutions; (b). Identification of the detailed goals of tarbawiyyah knowledge of perennial knowledge, with the main purpose of education in giving birth to superior and have a good personality; and (c). It is an urgent need to conduct studies, research, and publishing to develop Islamic culture and humanity in the context of modernity issue and its problems.

\section{Strengthening National Social-Based Scientific Networks for World Civilization} One of Indonesian Muslims' achievements after attaining Indonesian independence was the establishment and development of various educational institutions, including thousands of Islamic higher education, spread throughout the country. Especially since the last two decades, the development of the Islamic higher education world in Indonesia shows quite encouraging achievements. However, this achievement still requires hard work and better coordination to improve its quality, in accordance with its vision and mission towards a worldclass university with all the diversity of world challenges.

Seeing such a great academic spirit in the field of higher education and science, it is appropriate if we put great hope for the progress of this nation on the growth of Islamic educational institutions, especially Islamic universities today, including the State Institute of Islamic Studies (IAIN) and Islamic University (UIN) which continue to increase its excellent values. Various efforts

${ }^{30}$ Ismail, Peace Education and the Challenge of Modernity. 
to improve the quality of Islamic higher education have been carried out through various national, regional, and international collaborations. In the future, this collaborative network of scientific activities between nations, according to Yasid Ismail, in Peace Education and The Challenge of Modernity, will be away as well as a model of activities to improve the quality of higher education that is more effective and sustainable, where the orientation is not only for Indonesia but more than it is for the civilization of world nation-state. It also reduces the tension of conflict between nations of the world, which is currently so discouraging with millions of souls of innocent human children.

The era of globalization triggers the acceleration and expansion of change scale and opens up humanity's problems. It has encouraged new awareness among Muslims to expand their scientific networks and their Islamic educational institutions, which touch technical aspects of educational activities and science reproduction and touch on human values' substantial and fundamental aspects.

The rapid development of technology and science since the beginning of the 20th century turned out to be not entirely 'symmetrical' with the existence of ethics, values, and the greatness of human morality, which became a reference for the nature of science and truth, its purpose and use for the welfare and development of human civilization itself. Even the rapid development of science and technology has caused several humanitarian disasters, which include the outbreak of two world wars, the emergence of substitute wars (proxy wars) that occurred in several countries, especially in Africa and the Middle East when this is the arms race between powerful countries, environmental damage, global warming, food and energy crises, drug abuse, the deepening of the gap between rich and poor, social injustice, and so on.

Of course, the efforts to develop a scientific knowledge partnering between educational institutions need to be considered together. Later, it is truly contributive for developing a noble human civilization where the aspects of collaboration can be realized as (1) provision of world-scale Islamic education libraries and resource centers; (2) activating online library network with centers for the Islamic education study in Southeast Asia and the world; (3) conducting intensive studies of Islamic education's epistemology regularly, both by utilizing experts from within the country and abroad; (4). Conducting studies and restructuring the curriculum of Islamic higher education institutions; (5). Doing research and then writing textbooks in a particular discipline; and (6). Building a cyber network between enthusiasts and reviewers of Islamic studies, especially Islamic education, is at the national, regional, and international levels. The development of this institutional collaboration certainly requires a strong commitment across all variants of Islamic educational institutions, ranging 
from madrassas, pesantrenuntill Islamic higher education as the vanguard of Indonesian civilization, and 'the lighthouse of peace project' for world civilization.

\section{CONCLUSION}

The post-transnationalism paradigm of Indonesian Islamic education is an Islamic education that emphasizes the importance of values education of social harmony, tolerance, pluralism, peace, and mutual respect for the reality of the diversity of this motherland. In that context also, post-transnationalism of Islamic education can be interpreted as an ideology of Islamic education that carries at the same time promotes the importance of moderation values that live in the multicultural spirit of the national level, both in the window of madrassas, pesantren, and Islamic higher education.

The challenge of multiculturalism in Indonesian Islamic education in this archipelago historically is an accumulative problem with the dimension of social conflict, radicalism, and extreme fundamentalism where not a few of the nation's children deny the importance of respect for diversity as well as forcing the birth of oneness and uniformity under the pretext doctrinal religious orders. It also confirms that IndonesianIslamic education needs to get serious attention, both in madrassas, pesantren, and Islamic higher education, to produce tolerant, moderate, and inclusive students. The reality of the challenge of national multiculturalism for the world of Islamic education in this archipelago is the grand design of systematic efforts from certain transnational religious groups to teach hard-line religious doctrines. On the other hand, it must be admitted that Islamic education has been more exclusive than inclusive. In its implementation, Islamic education's teaching emphasizes one's religion's truth claims, without accompanied by a sense of tolerance and adequate appreciation of religious diversity. Thus, developing Indonesian multicultural Islamic education today is necessary, and building multicultural awareness of the importance of peace and social harmony values is becoming increasingly alarming today.

The management of multi c ultural resolution of Indonesian Islamic education for the peace of world civilization must at least carry three main agendas that are very urgent in realizing the post-transnationalism paradigm in the future, namely: (a) developing humanistic Islamic education curricula at various educational l evels, both madrassas, pesantren and Islamic higher education where the objectives, materials, and methods of Islamic education are developed in the same direction, and in line with the spirit of this multicultural archipelago which emphasizes the importance of growing empathy, caring for students, appreciation for diversity, and dialogic communication of educatorsstudents in learning that is fun and humanizes humans; (b) strengthening the management moderation of Islamic educational institutions oriented towards 
developing a comprehensive understanding of Islam, increasing support for peace and respecting hum an values, and recognizing religious, cultural, and political plurality; and (c) strengthening scientific networks for world civilization which is supported by commitment and scientific knowledge partnering with various institutions, both on a national, regional and international scales by always carrying the spirit of this multicultural archipelago as a "window of world science" as well as peace of world civilization. 


\section{REFERENCES}

Abdul Mujib, Abdul Mujib. Ilmu Pendidikan Islam. Jakarta: Kencana Prenada Media Group, 2007.

Abdurrahman, Muhammad Husein. Al-Tarbîyah al-Islâmîyah al-Asyriyah. Lebanon: Dâr al-Fikr al-'Arabî, 2012.

Azra, Azyumardi. Pendidikan Islam: Tradisi Dan Modernisasi Menuju Milenium Baru. Logos Wacana Ilmu, 1999.

Baidhawy, Zakiyuddin. Pendidikan Agama Berwawasan Multikultural. Jakarta: Erlangga, 2005.

Bill, Hendrick. Religion and Education in Modern Society. New York: Manhattan Ltd Press, 2014.

Cardinas, Jose A. Multicultural Education: A Generation of Advocacy. Amerika: Simon and Schuter Custom Publishing, 2014.

Fazlurrahman. Islam and Modernity. New York: Chicago University Press, 1986.

Garcia, Ricardo L . Teaching in Pluralistic Society. New York: Row Publisher, 2013.

Geers, Richard. How to Be a Great Leader: Kiat Sukses Menjadi Pemimpin Besar. Translator. Ariyanto Harahap. Surabaya: Cahaya Ilmu, 2016.

Grimmit, Michael. Religious Education and Human Development. Great Britarian: McCrimmon, 2012.

Ismail, Yasid. Peace Education and the Challenge of Modernity. New York: David McKay Company, 2006.

Ma'arif, Syafi'I. Islam Dan Kedamaian Sosial. Yogyakarta: Bintang Pustaka, 2009.

McNeil, Edwind, and John D. Contemporary Humanistic Curriculum. New York: McMahon International Book Ltd., 2013.

Naim, Ngainun. "'Strategi Penanganan Radikalisme Dan Terorisme Di Indonesia: Perspektif Pendidikan."' Presented at the National Simposium about "Memutus Mata Rantai Radikalisme dan Terorisme," Jakarta, July 15, 
2011. http://www.lazuardibirru.org/wp-content/uploads/else/pdf/strategipenganan-radikaliseme-dan-teroris me.pdf.

Pieters, Hans Luck. Resolution Management for Multicultural Education. New York: Prentice Hall Ltd, 2018.

Power, Clark. F. Moral Education. New York: Greenwood Publishing Group, 1988.

Pratte, Richard. Ideology and Education. New York: David McKay Company, 1998.

Qordhawi, Yusuf al-. Al-Islam Wa Awsatuhu Fi al-Tarbawiyah. Lebanon: Dar el-Kalam, 2013.

"Republika," March 26, 2017.

Roger, Carl. Learning and Teaching Humanist. New York: Commons License: Attribution Non-Commercial, 2015.

Syauqi, Ahmad. At-Tarbiyah Wa Uslubuha Fi al-Mujtama' al-Asy'ri. Maroko: Dar al-Khitab, 2015.

"The Report of Religion Research Institute of Religious Affairs in 2017." Accessed April 13, 2019. www/http.balitbang.kemenag.go.id.

"The Report of The Wahid Institute on National Seminar about 'Terorisme Dan Radikalisme: Tantangan Kekinian Islam Nusantara.” UIN Syarif Hidayatullah Jakarta, August 19, 2016.

Thoyib, Muhammad. Model Pengembangan Pendidikan Islam Multikultural Di Indonesia. Ponorogo: STAIN Po-Press, 2016.

Tobroni. Relasi Kemanusiaan Dalam Keberagamaan (Mengembangkan Etika Sosial Melalui Pendidikan). Bandung: Karya Putra Darwa, 2012.

Yaqin, Haqqul. Agama \& Kekerasan Dalam Transisi Demokrasi Di Indonesia. elSAQ Press, 2009.

Republika, April 28, 2018. 